\title{
A Systematic Review of Research on Pre-Service TESOL Teachers' Emotions
}

\author{
Saadet Korucu Kış ${ }^{1 *}$ \\ 'Necmettin Erbakan Üniversitesi, Ahmet Keleşoğlu Eğitim Fakültesi, İngilizce Öğretmenliği, Konya, Türkiye \\ ORCID: S. Korucu Kış (0000-0002-1128-1747)
}

\begin{abstract}
The study of pre-service teachers' emotions has long been marginalized within the field of teaching English to speakers of other languages (TESOL). Yet, with the advent of a sociocultural turn in the field and an emotional turn in educational science, there has been growing interest in the role of emotions in would-be teachers' professional learning. The purpose of this study is to examine the demographic (i.e. year of publication, contributing countries and methodologies used) and topical trends concerning pre-service teacher emotionality in TESOL teacher education. For this purpose, studies published in journals that were included in Social Science Citation Index (SSCl) were reviewed and a total of 19 research articles were analyzed using both deductive and inductive analysis techniques. Concerning the demographic trends, the findings revealed that there has been an increase in the number of research articles within the last decade. Turkey and China are among the major contributing countries and the most frequently used research methodology is qualitative method. As to topic trends, "Emotions and Identity Formation", "Emotions in relation to Language Learning" and "Emotional Responses to University Coursework" are found to be as the most popular research topics. As a result of the analysis, current gaps in research on TESOL education are identified and suggestions are made for future work.
\end{abstract}

Keywords: Emotions; emotionality; TESOL; pre-service teachers; teacher education

\section{İngilizce Öğretmenliği Eğitimi Alanında Duygular Üzerine Sistematik Bir Analiz}

Özet: Öğretmen adaylarının duygularının incelenmesi, diğer dilleri konuşanlara İngilizce öğretme (TESOL) alanında uzun süredir marjinalleştirilmiştir. Ancak, alanda başlıca sosyokültürel bir dönüşümün yaşanması ve eğitim bilimleri alanında da duygusal bir devrimin ortaya çıkmasıyla birlikte, İngilizce öğretmeni adaylarının mesleki öğrenmelerinde duyguların rolüne artan bir ilgi olmuştur. Bu çalışmanın amacı, TESOL öğretmen eğitiminde öğretmen adaylarının duygusallığına ilişkin demografik (yayın yılı, katkıda bulunan ülkeler ve kullanılan metodolojiler) ve konu eğilimlerini incelemektir. Bu amaçla Sosyal Bilimler Atıf Endeksi'ne (SSCl) dahil olan dergilerde yayınlanan çalışmalar incelenmiş ve toplam 19 araştırma makalesi hem tümdengelim hem de tümevarım metodları kullanılarak analiz edilmiştir. Demografik eğilimlerle ilgili olarak, bulgular, son on yılda araştırma makalelerinin sayısında bir artış olduğunu ortaya koymuştur. Türkiye ve Çin en büyük katkı sağlayan ülkeler olarak tespit edilmiş ve en sık kullanılan araştırma metodolojisinin nitel yöntem olduğu görülmüştür. Konu eğilimlerine gelince, "Duygular ve Kimlik Oluşumu", "Dil Öğrenimine İlişkin Duygular” ve "Üniversitede Alınan Eğitime Yönelik Duygusal Tepkiler” en popüler araştırma konuları olarak bulunmuştur. Analiz sonucunda, TESOL eğitimi ile ilgili araştırmalardaki mevcut boşluklar tespit edilmiş ve gelecekteki çalışmalar için önerilerde bulunulmuştur.

Anahtar kelimeler: duygu; İngilizce öğretmenliği; öğretmen eğitimi

\section{INTRODUCTION}

Teaching is an emotionally laden profession. Day in and day out, teachers are expected to respond to the demands of various educational stakeholders (e.g. students, administrators, parents, and governmental authorities) as part of their job (Darby, 2008). When addressing the opportunities and challenges posed by different constituencies, they experience a wide array of emotional responses. While positive emotions such as happiness,

*Yazışma Adresi / Address for Correspondence:

S. Korucu Kış, Email: skorucukis@gmail.com

Geliş Tarihi / Received Date: 31.05.2021

Kabul Tarihi / Accepted Date: 19.07.2021

Doi: 10.32329/uad.945439 success and enjoyment make teachers feel satisfied and motivated, such negative emotions as anxiety and disappointment cause insecurity and frustration (Timoštšuk \& Ugaste, 2012). Moreover, the contemporary literature suggests that one of the necessary conditions of sustaining effective teaching is to ensure the maintenance of positive psychology in instructional settings (e.g. Bullough, 2011). In that, positive emotions allow teachers to generate more varied ideas to cope with the challenges that occur in their everyday work. They also help teachers set ambitious goals for their ongoing involvement with the practice of teaching itself (Sutton \& Wheatley, 2003)

Despite inhering in the nature of teaching practice, teacher emotionality has long been marginalized to cog- 
nitive aspects of teacher learning in the field of applied linguistics. According to Richards (2020), the neglect of emotions in the professional literature can be explained by the fact that "Emotions were often typically regarded as "soft" and unobservable in comparison to the "hard" quantifiable and rational facts about second language learning and teaching that were the focus of much research attention from the 1970s" (p.445). However, with the advent of sociocultural turn in language teacher education, there has been growing interest in teacher emotionality and its impact on TESOL teachers' professional lives (Nguyen, 2019). Martinez Agudo (2018) states that these studies mostly focus on burnout or stress levels of language teachers and non-native English teachers' anxieties about their language proficiency.

In comparison to research into in-service teachers' emotions, pre-service teacher emotionality still remains underexplored in the field of TESOL. Shoffner (2009) notes that pre-service teachers concentrate more on the emotional and relational aspects of teaching practice. In the same vein, Nguyen (2019) suggests that as learning to teach is an emotionally intense practice, recognizing pre-service teachers' emotions and supporting them can help would-be teachers respond to the challenges arising in their professional learning journey productively. That being said, Lemarchand-Chauvin and Tardieu (2018) contend that "pre-service teachers have for a long time looked for support to address the emotional aspects of their work without really being heard by the educational authorities" (p. 425). Given emotions experienced during professional learning activities in initial teacher education programs are far too influential on pre-service teachers' questioning of their suitability as a teacher, acknowledging pre-service teacher emotionality is essential. In this regard, a systematic review of research into pre-service TESOL teachers' emotions can be of high value to reveal current trends, gaps and areas for future work in a research area that is still in its infancy.

\section{THEORETICAL BACKGROUND}

Learning to teach has long been considered a cognitive endeavor in TESOL teacher education. Drawing on Shulman (1987), a typical language teacher education program aims to develop pre-service teachers' knowledge of subject matter, general pedagogy, curriculum, learners and learner characteristics, educational settings, educational purposes and values, and philosophical and historical grounds that underlie these ends. In the same vein, Lemarchand-Chauvin and Tardieu (2018) state that most teacher education institutions have sought for preparing linguistically and didactically trained teachers ignoring the affective side of teaching for a long time. However, with the arrival of sociocultural perspectives in language teacher education, it has been recognized that learning to teach entails not only mastering content knowledge and communicating it but also learning how to manage emotional aspects of teaching (Martinez Agudo, 2018; Lemarchand-Chauvin \& Tardieu, 2018).

From a sociocultural stance, a strong relationship exists between cognition and emotion and the separation of these two interdependent constructs is one of the major flaws of traditional approaches to research on cognitive processes (Nguyen, 2019). The sociocultural view maintains that human thinking involves both mental and affective tendencies and human thought can be fully understood if the affective-volitional aspect of human thought is comprehended (Nguyen, 2018). Interacting with and influencing each other, these constructs are inseparably intertwined in the complex world of teaching and determine the quality of instruction (Day \& Gu, 2009). In this sense, Golombek and Doran (2014), aptly pointed out that "Emotion, cognition, and activity continuously interact and influence each other, on both conscious and unconscious levels, as teachers plan, enact, and reflect on their teaching" (p.105). Therefore, recent research (e.g Golombek \& Doran, 2014; Martinez Agudo, 2018; Nguyen, 2019) suggests that the popular term of teacher cognition (Borg, 2003) in the field of TESOL teacher education be reconceptualized beyond the cognitive dimension of knowledge, belief and thought and include emotions as an integral dimension of professional learning.

During university coursework and practicum, pre-service teachers experience various feelings such as anger, anxiety, disappointment, doubt, irritation, fear, love, enthusiasm, satisfaction, pride and so on (Teng, 2017). According to Anttila et al. (2016), such emotions directly influence novice teachers' perceived success when they start their career. Richards (2020) furthers that teacher emotionality plays a decisive role in teachers' choice of instructional activities such as involving in collaborative professional development activities (e.g. peer observation and team teaching), undertaking individual or groupbased activities, creating a cooperative or competitive classroom environment, making use of edutainment activities (e.g. songs, games and stories) and selecting commercial or teacher-made materials. Put simply, the creation of dull or lively classes is closely connected to teachers' emotions with regard to the practice of teaching. Emotional properties teachers have act as a filter for how they view and perform teaching.

In view of these discussions, it is reasonable to advocate that although a cognitive orientation has a significant role to play in providing pre-service teachers with the necessary knowledge and skills to teach, it is equally essential to acknowledge the affective side of learning to teach (Yuan \& Lee, 2016). As would-be teachers often experience a lonely journey during the initial years of teaching (Lindqvist et al., 2017), the development of emotional competence during university coursework can facilitate their transition into professional practice. Rich- 
ards (2020) indicates that emotionally competent teachers can understand the nature of both learner and teacher emotions, manage their emotions to reflect the professional identity of a teacher, use emotions to enhance student engagement in learning, utilize strategies to address learner feelings, change the affective climate in the classroom, cope with distressful situations and strategically maneuver when encountering the challenges of everyday classroom life. Therefore, pre-service teachers should develop an awareness of the fact that emotions not only affect the quality of their teaching experiences but also their students' learning experiences (Hargreaves, 1998).

Along with informing pre-service teachers about making decisions about instructional practices and guiding their behaviors of how to enact teaching, emotions also influence the social interactions taking place between wouldbe teachers and teacher educators, mentor teachers, and learners. In these dialogic exchanges, they experience a variety of unpleasant and pleasant emotions. Research (Anttila et al., 2016; Martinez Agudo, 2018) suggests that while the latter contributes to the development of a positive professional identity, the former often results in unproductive professional identities.

To put in a nutshell, the process of becoming a teacher is replete with emotional ups and downs due to the uncertain and complex nature of everyday school life. Hence, teacher education programs need to offer courses that prepare pre-service teachers to productively respond to conflicting emotions they encounter during their learning to teach experiences. Considering that nearly 50 percent of early career teachers leave their jobs (Zembylas, 2007 as cited in du Plessis \& Marais, 2013) and one of the reasons for teachers' dropping out of the profession might be related to negative and counter-productive emotions (du Plessis \& Marais, 2013), the provision of emotional education is of considerable importance to train language teachers who can recognize and consider emotional aspects of learning and teaching, and competently manage emotional challenges and pressures.

\subsection{Purposes and significance of the study}

Teacher education is considered "a continuum from initial teacher education through induction to continuing professional learning" (Madalinska-Michalak \& Bavli, 2018, p.404). While learner achievement is closely germane to teachers and their instructional practices, teachers and their professionalism rely on the quality of education provided by teacher training colleges (Darling-Hammond, 2017). The crux of research on teacher emotionality suggests that "educating the mind without educating the heart is no education at all" (Aristotle as cited in Dewaele et al., 2018). Against this backdrop, the present study contends that a focus on would-be teachers' emotions is essential since emotional responses, challenges and dilemmas experienced during teacher education are likely to impact their acquisition of teaching knowledge and skills, and their practices as in-service teachers. Further, it maintains that the issue of emotionality is of particular interest to pre-service TESOL teachers since they will teach a language other than their mother tongue, which may bring about deep anxiety and tension in them. Yet, despite their central role, the issue of emotions in TESOL teacher education remains unclear. If teacher emotionality is to become a recognized field of research, there should be more research investigating its nature and effects. In this regard, a systematic review of research can be of high value to reveal current trends, gaps and areas for future work in the field. To these ends, the present study focuses on addressing the following research questions:

1. What are the demographic trends in research on pre-service TESOL teachers' emotions?

2. What are the research topics related to pre-service TESOL teachers' emotions?

\section{METHOD}

This paper aimed to select, identify and synthesize primary research studies on pre-service TESOL teachers' emotions. Hence, a systematic review was conducted to seek answers to the research questions of the study. Unlike traditional literature review methodology, a systematic review is driven by protocols (Bearman et al., 2012). It provides a summary of existing research and consists of several stages: formulating research questions, defining inclusion/exclusion criteria, searching literature, appraising the search results, synthesizing findings and drawing conclusions from the included studies (Petticrew \& Roberts, 2006).

\subsection{Data collection}

A systematic search was conducted in the SSCI database via the website of Web of Science (WOS). The reason behind the selection of this database was to reach papers that were published in leading journals with high impact factors. Advanced search engine of WOS was used and the search terms included "affect", "emotion", "feeling", "mood", “teacher", "language", "English", "EFL", "ESL", "TESOL", "L2", "ELT" and "foreign". While conducting the search, the preferred Boolean operators were "AND" and "OR". No time span was specified for date of publication. The inclusion criteria of the study were set as follows: being identified as research article in the SSCI database, being published in English, including pre-service TESOL teachers as participants, using and retaining emotions as a study construct, and being located in the education and language related categories of web of science (i.e. education educational research, psychology educational, linguistics, education scientific disciplines, education special, and language linguistics). The titles, keywords and abstracts of returned results were carefully examined by two coders including the author. In cases 
when the research topic was not clearly comprehended by means of aforementioned sections, a full-text examination was performed. The appraisal process yielded 19 research studies for inclusion.

\subsection{Data analysis}

In line with the purposes of the study, the articles were analyzed based on two main categories: demographic trends (i.e. year of publication, contributing countries and methodologies used) and topical trends. The method of content analysis was used to analyze the documents. First, a form was created via Microsoft Excel software. Next, adopting a deductive approach, it was filled with the preconceived notions of the first research question and related descriptive data from the articles. As to identifying topical trends, the retrieved documents were read for several times to initiate the inductive coding process and generate typologies. To ensure intercoder reliability, two coders (including the researcher) were employed. Discrepancies in codings were resolved through discussion and consensus. As a further note, since this is a review study and does not involve research subjects, ethical approval was not sought.

\section{RESULTS}

\subsection{Demographical trends in research on pre-service TESOL teachers' emotions}

To address the first research question, the subcategories investigated by the researcher involved the distribution of the papers over years and contributing countries along with the research methodologies used. The following section describes each subcategory.

\subsubsection{Number of studies on pre-service TESOL teachers'} emotions in SSCI-indexed journals

Collected in April 2021, the number of studies related to research on pre-service TESOL teachers' emotions is displayed in Figure 1. The results of this study revealed that all the studies except for one were published within the last decade. Among the 19 papers reviewed, the first study that examined pre-service TESOL teachers' emotions was published in 2009. As of that year, there has been an increase in the number of studies.

\subsubsection{Countries contributing to the literature on emo- tionality in TESOL teacher education}

Figure 2 presents that a variety of countries inquired into pre-service TESOL teachers' emotions. It also shows that the highest number of studies was carried out in Turkey $(n=6)$ followed by China $(n=4)$

\subsubsection{Research methodologies used}

As for the research methodologies adopted in the reviewed studies on pre-service TESOL teachers' emotions, Figure 3 displays that the most frequently used research methodology was the qualitative method $(n=8)$ closely followed by the mixed method $(n=6)$ and the quantitative method in the selected studies $(n=5)$.

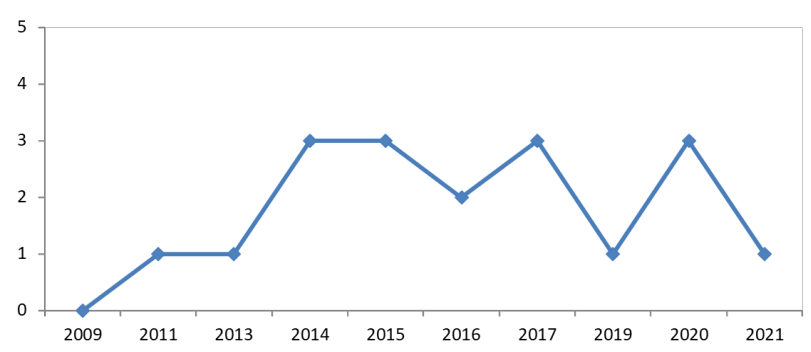

Figure 1. Number of papers published in SSCl-indexed journals

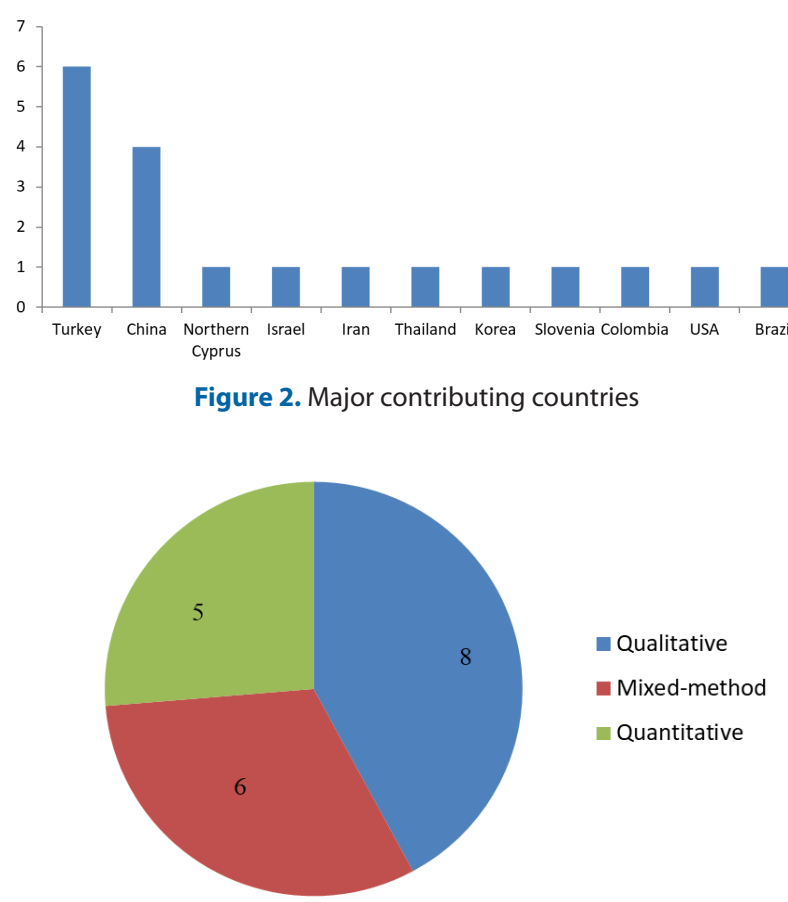

Figure 3. Research methodologies adopted in studies on emotions in TESOL teacher education

\subsection{Research topics in research on pre-service TESOL teachers' emotions}

The second research question of the study explored the topical trends pertaining to pre-service TESOL teachers' emotions. As a result of the inductive content analysis, three main themes were generated as to the issue of emotions in initial teacher education. As revealed in Table 1, the most published research topic was "emotions and identity formation". Nine out of 19 studies focused on the pivotal part emotions play in the personal (Gonzalez, 2020; Tashma Baum, 2014) and professional (de Laurentiis Brandao, 2021; Eren 2014; Lin et al., 2019, Paker, 2011, Yuan \& Lee, 2015; Yuan \& Lee, 2016; Yüksel, 2014) identity construction of would-be teachers. This was followed by "emotions in relation to the learning of language skills" and "emotional responses to university coursework". Five out of 19 studies examined pre-service teachers' foreign language anxiety with specific reference to different language skills. While, three of those studies addressed emotional challenges faced during oral communication (Fallah, 2014, Öz et al., 2015, Tüm \& Kunt, 2013), one of them was concerned with understanding 
the effects of anxiety on pre-service teachers' listening comprehension (Bekleyen, 2009), the other one was related to exploring would-be teachers' level of foreign language pronunciation anxiety and its reduction through psycho-social training (Kralova et al., 2017). Also, five out of 19 studies investigated pre-service teachers' emotional responses to activities undertaken in initial teacher education programs. In one portion of his study, Eren (2016) investigated the relationship between pre-service teachers' boredom, coping strategies for boredom and emotional engagement for the purpose of answering whether boredom coping strategies can decrease boredom and increase pre-service teachers' emotional engagement during class hours. In their qualitative study, one of the purposes of Guerrettaz et al. (2020) was to develop pre-service teachers' understanding of affective investment in English language learners. With this in mind, the researchers further investigated the effects of embodied classroom activities on pre-service teachers' empathy development for language learners. Using critical incidents to create cognitive and emotional dissonance in their learners, Hall and Townsend (2017) probed into the difficulties pre-service teachers faced in practice and attempted to encourage would-be teachers to resolve these challenges in order to better prepare them for the rigors of everyday teaching. In one portion of their study, Kim et al. (2017) examined how learner emotions, perceptions of task difficulty, confidence in task performance,

Table 1. Topic trends with regard to pre-service TESOL teachers' emotions

\begin{tabular}{|c|c|c|c|}
\hline Categories & Codes & $f$ & Research Studies \\
\hline \multirow[t]{2}{*}{$\begin{array}{l}\text { Emotions and } \\
\text { identity forma- } \\
\text { tion }\end{array}$} & $\begin{array}{l}\text { Emotions expe- } \\
\text { rienced during the } \\
\text { construction of pro- } \\
\text { fessional identity }\end{array}$ & 7 & $\begin{array}{l}\text { de Laurentiis Brandao } \\
\text { (2021), Eren 2014; Lin et al., } \\
\text { (2019), Paker (2011), Yuan } \\
\text { and Lee (2015), Yuan and } \\
\text { Lee (2016), Yüksel (2014) }\end{array}$ \\
\hline & $\begin{array}{l}\text { Emotions expe- } \\
\text { rienced during the } \\
\text { construction of } \\
\text { self-identity }\end{array}$ & 2 & $\begin{array}{l}\text { Tashma Baum (2014), } \\
\text { Gonzalez (2020) }\end{array}$ \\
\hline \multirow[t]{3}{*}{$\begin{array}{l}\text { Emotions in } \\
\text { relation to the } \\
\text { learning of langu- } \\
\text { age skills }\end{array}$} & $\begin{array}{l}\text { Oral communication } \\
\text { anxiety }\end{array}$ & 3 & $\begin{array}{l}\text { Fallah (2014), Öz et al., } \\
\text { (2015), Tüm and Kunt } \\
\text { (2013) }\end{array}$ \\
\hline & Listening anxiety & 1 & Bekleyen (2009) \\
\hline & $\begin{array}{l}\text { Pronunciation } \\
\text { anxiety }\end{array}$ & 1 & Kralova et al. (2017) \\
\hline \multirow[t]{5}{*}{$\begin{array}{l}\text { Emotional } \\
\text { responses to } \\
\text { university cour- } \\
\text { sework }\end{array}$} & $\begin{array}{c}\text { Emotions about } \\
\text { task-based language } \\
\text { learning }\end{array}$ & 1 & Kim et al. (2017) \\
\hline & $\begin{array}{c}\text { Emotional reactions } \\
\text { to teacher educator } \\
\text { feedback }\end{array}$ & 1 & $\begin{array}{l}\text { Li and Curdth-Christiansen } \\
\text { (2020) }\end{array}$ \\
\hline & $\begin{array}{l}\text { Empathy develop- } \\
\text { ment for English } \\
\text { language learners }\end{array}$ & 1 & Guerrettaz (2020) \\
\hline & $\begin{array}{l}\text { Emotional disso- } \\
\text { nance during critical } \\
\text { incidents }\end{array}$ & 1 & Hall and Townsend (2017) \\
\hline & $\begin{array}{l}\text { Boredom and enga- } \\
\text { gement during class } \\
\text { hours }\end{array}$ & 1 & Eren (2016) \\
\hline
\end{tabular}

task enjoyment, beliefs about learning opportunities and task motivation interact with each other throughout a semester. Finally, in one portion of their study, Li and Curdth-Christiansen (2020) examined how pre-service teachers made sense of the teacher educator feedback affectively and how emotional reactions to praises and criticisms affect their long-term uptake of teacher feedback. Table 1 presents these themes and the frequency counts for each sub-theme.

\section{DISCUSSION AND CONCLUSIONS}

Research articles published in leading journals contribute to the scholarly literature providing a sound theoretical and empirical foundation. Hence, SSCI-indexed journals which require strict and rigorous criteria for publication can be said to include papers with high impact on the development of a research field or topic. In this sense, it is of substantial benefit to conduct systematic reviews on studies indexed in these journals to explore current trends and lacunas in research areas that are still in infancy. With this in mind, the present study set out to identify demographic and topical trends in the arena of emotionality in TESOL teacher education which remains in shadows compared to affective issues related to in-service teaching practice and second language acquisition. In alignment with research purposes and inclusion criteria of the study, 19 research articles retrieved from the SSCI database were analyzed.

To begin with, the demographic trends in the research area, the analysis results showed that there has been an increase in the number of studies on pre-service TESOL teachers' emotions since 2009. The rising number of research articles can be explained by the sociocultural turn in the field along with the affective turn experienced in educational science since late 1990s due to an "emotional revolution" in psychology (Sutton \& Wheatley, 2003, p. 328). According to Martinez Agudo (2018), although intellectual educational traditions have long stressed the cognitive aspect of teacher learning, recent developments have advanced the idea that teaching is an emotionally laden profession and teacher education programs are emotionally-inundated places where pre-service teachers experience a wide spectrum of emotions in the transition process of being a student and becoming a teacher. As to major contributing countries to the field, eleven different countries were identified despite the low number of studies retrieved. Among them, Turkey and China had the most publications. However, despite the variety of countries, there is a critical need for more studies both from the same and other cultures to provide a strong theoretical and empirical foundation for the study of teacher emotions that has been viewed as too complex and vague to research for years; yet residing at the core of teaching practice (Richards, 2020). The final sub-category was concerned with research methodologies used in 
the research articles. The most frequently used was qualitative research method. This finding can be explained by the research focus of the reviewed research articles. Given most of the studies centered on the pivotal role of emotions in the identity construction, it was appropriate to use qualitative research to explore a phenomenon and develop a detailed understanding of the research problem (Creswell, 2012).

As to the topical trends, the most studied theme in association with pre-service TESOL teachers' emotions was identity formation. Needless to say, emotions significantly influence pre-service teachers' construction of their professional identity. In that, emotions act as intensifiers or amplifiers when prospective teachers reflect on events related to their experiences of learning about teaching (Sutton \& Wheaton, 2003). According to Timoštšuk and Ugaste (2012), pleasant emotions experienced during initial teacher education help pre-service teachers create a positive image of themselves as practicing teachers. This, in turn, motivates them to resolve teaching dilemmas through objective and creative decisions they make in the selection of manifold instructional strategies. The researchers further that negative emotions, on the other hand, cause stress and anxiety and confound would-be teachers' expectations of the teaching profession. Being a teacher of a foreign language also involves changes in one's self-identity. Pre-service teachers' positive emotions toward the target language help them develop a richer self-identity embracing different cultural viewpoints. Along similar lines, Tashma Baum (2014) states that for most of the conscious learners of English learning it is "less a blind adherence and more a self-motivated mining of the English languaculture for potentially self-enriching and self-empowering resources, whether linguistic, cultural, or communicative" (p.419).

Emotions in relation to the learning of language skills was another recurrent theme in the discourse of pre-service TESOL teachers' emotions. Emotional responses such as anxiety, unwillingness, tension, apprehension, and uneasiness are among the most frequently experienced affective states students report in contexts where English language is learnt as a foreign language (Bekleyen, 2009; Oz et al., 2015). Due to lack of input and output opportunities, even students with higher proficiency levels such as pre-service teachers suffer from negative emotions related to their performance in English (Korucu-Kış \& Şanal, 2020). In alignment with the first theme obtained in the study, Kralova et al. (2017) state that the foreign language anxiety (FLA) encountered in TESOL teacher education programs can be attributed to the existence of a fragile second self. In other words, one of the reasons that pre-service teachers are overcome with negative emotions in their learning experiences is that prospective teachers associate FLA with identity-based constructs.
The final theme in relation to pre-service TESOL teachers' emotions was concerned with pre-service teachers' emotional responses to university coursework. According to Martinez Agudo (2018), learning to teach is an emotionally fraught experience. Pre-service teachers go through myriads of emotions during classroom activities in their interactions with teacher educators and the subject matter. While positive feelings experienced can affect their intention to make use of the newly learned material, challenging tasks can be a struggle for them and impinge on their engagement in classroom learning (Richards, 2020; Teng, 2017). Setting foot in teacher education programs with traditional views of teaching (Korucu-Kış \& Kartal, 2019), pre-service teachers experience emotional dissonance encountering current theories of language teaching, roles of language teachers, characteristics of best practices and the way English is used in classroom teaching for the first time (Richards, 2020). They may find the new course content difficult to accommodate with their robust perceptions of transmissive learning, leading to displeasure and annoyance (Golombek \& Doran, 2014). Hence, Li and Curdt-Christiansen (2014) contend that supportive teacher educator feedback plays a critical role in facilitating pre-service teachers' learning and increasing academic performance.

The findings of the study suggest that despite a recent increase in the number of studies, research on pre-service TESOL teachers' emotions still remains limited. In order to validate emotions as part of initial language teacher education, more studies with different methodologies need to be conducted with different populations to establish a theoretical and methodological background that can guide teacher educators. The findings also show that research on pre-service TESOL teachers' emotions revolves around the role of emotions in the identity construction, foreign language anxiety and professional learning. These results indicate a lack of instructional design studies that focus on teaching methods with the capacity of creating emotional experiences, helping teacher educators to exploit emotional rises to pre-service teachers' own advantage and encouraging prospective teachers to regulate their emotions. Additional research could be directed to explore different emotions other than anxiety in the language learning process. Future research may also investigate the long-term effects of emotions experienced in university coursework on on-the-job performance of would-be teachers.

Despite the significant implications of the present study, the most important limitation lies in the fact that specific criteria were set to explore research on pre-service TESOL teachers' emotions. Inclusion of different types of studies (e.g. book chapters, reviews, conference papers) aside from research articles and making search in other databases (e.g. Eric, Scopus) than SSCI database might have yielded different results. Thus, there is a need for future work that uses different selection criteria. 


\section{REFERENCES}

Anttila, H., Pyhältö, K., \& Soini, T. (2016). How does it feel to become a teacher? Emotions in teacher education. Social Psychology Education, 19, 451-473. https://doi.org/10.1007/ s11218016-9335-0

Bearman, M., Smith, C. D., Carbone, A., Slade, S., Baik, C., Hughes-Warrington, M., \& Neumann, D. L. (2012). Systematic review methodology in higher education. Higher Education Research \& Development, 31(5), 625-640. https:// doi.org/10.1080/07294360.2012.702735

Bekleyen, N. (2009). Helping teachers become better English students: Causes, effects, and coping strategies for foreign language listening anxiety. System, 37, 664-675. https:// doi:10.1016/j.system.2009.09.010

Borg, S. (2003). Teacher cognition in language teaching: A review of research on what teachers think, know, believe and do. Language Teacher, 36, 81-109. https://doi.org/10.1017/ S0261444803001903

Bullough, R. V. (2011). Hope, happiness, teaching and learning. In C. Day \& J. C. K. Lee (Eds.), New understandings of teacher's work: Emotions and educational change (pp. 17-32). NewYork: Springer.

Creswell, J. W. (2012). Educational research: Planning, conducting, and evaluating quantitative and qualitative research. Pearson.

Darby, A. (2008). Teachers' emotions in the reconstruction of professional self-understanding. Teaching and Teacher Education, 24(5), 1160-1172. https://doi.org/10.1016/j. tate.2007.02.001

Darling-Hammond, L. (2017). Teacher education around the world: What can we learn from international practice? European Journal of Teacher Education, 40(3), 291-309. https://doi.org/10.1080/02619768.2017.1315399

Day, C., \& Gu, Q. (2009). Teacher emotions: Well-being and effectiveness. In P. A. Schutz \& M.

Zembylas (Eds.), Advances in teacher emotion research (pp. 15-32). New York: Springer.

de Laurentiis Brandao, A. C. (2021). First experiences of teaching EFL in metaphors. Teaching and Teacher Education, 97, 1-11. https://doi.org/10.1016/j.tate.2020.103214

du Plessis, E. C. \& Marais, P. (2013). Emotional experiences of student teachers during teaching practice: A case study at Unisa. Progressio, 35(1), 206-222.

Eren, A. (2014). Relational analysis of prospective teachers' emotions about teaching, emotional styles, and professional plans about teaching. The Australian Educational Researcher, 41(4), 381-409. https://doi.org/10.1007/s13384013-0141-9.

Eren, A. (2016). Unidirectional cycles of boredom, boredom coping strategies, and engagement among prospective teachers. Social Psychology of Education, 19(4), 895-924. https://doi.org/10.1007/s11218-016-9348-8

Fallah, N. (2014). Willingness to communicate in English, communication selfconfidence, motivation, shyness and teacher immediacy among Iranian English-major undergraduates: A structural equation modeling approach. Learning and Individual Differences, 30, 140-147. https:// doi.org/10.1016/j.lindif.2013.12.006
Golombek, P., \& Doran, M. (2014). Unifying cognition, emotion, and activity in language teacher professional development. Teaching and Teacher Education, 39, 102-111. https://doi.org/10.1016/j.tate.2014.01.002

González, J. J. V. (2019). Prospective English teachers re-examining language ideologies in telecollaboration. Computer Assisted Language Learning, 33(7), 732-754. https://doi.org /10.1080/09588221.2019.1590419.

Guerrettaz, A. M., Zahler, T., Sotirovska, V., \& Boyd, A. S. (2020). 'We acted like ELLs': A pedagogy of embodiment in preservice teacher education. Language Teaching Research. Advance online publication. https://doi. org/10.1177/1362168820909980.

Hall, J. M., \& Townsend, S. D. C. (2017). Using critical incidents and E-portfolios to understand the emergent practice of Japanese student-teachers of English. Teaching and Teacher Education, 62, 1-9. https://doi.org/10.1016/j. tate.2016.10.017

Hargreaves, A. (1998). The emotional practice of teaching. Teaching and Teacher Education, 14(8), 835-854. https:// doi.org/10.1016/S0742-051X(98)00025-0

Kim, Y., Jung, Y., \& Tracy-Ventura, N. (2017). Implementation of a localized task-based course in an EFL context: A study of students' evolving perceptions. TESOL Quarterly, 51, 632660. https://doi.org/10.1002/tesq.381

Korucu Kış, S., \& Kartal, G. (2019). No pain no gain: reflections on the promises and challenges of embedding reflective practices in large classes. Reflective Practice, 20(5), 637-653. https://doi.org/10.1080/14623943.2019.1651715

Korucu-Kış, S., \& Şanal, F. (2020). Bridging in-class and out-ofclass learning through podcast-intertwined collaborative tasks to reduce EFL speaking anxiety among higher proficiency learners. International Online Journal of Education and Teaching, 7(2), 636-653.

Kralova, Z., Skorvagova, E., Tirpakova, A., \& Markechova, D. (2017). Reducing student teachers' foreign language pronunciation anxiety through psycho-social training. System, 65, 49-60. https://doi:10.1016/j.system.2017.01.001

Lemarchand-Chauvin, M.C., \& Tardieu, C. (2018). Teachers' emotions and professional identity development: Implications for second language teacher education. In Martínez Agudo (Eds.), Emotions in second language teaching: Theory, research and teacher education, pp.425-443. Springer.

Li, F., \& X. Curdt-Christiansen. (2020). Teacher Feedback in UK Higher Education: Affective and Cognitive Perceptions of Chinese Postgraduate Students. International Journal of Educational Research. 104, 1-12. https://doi:10.1016/j. ijer.2020.101674.

Lin, Z., B. Wu, F. Wang, \& D. Yang. (2019). Enhancing Student Teacher Motivation through Mentor Feedback on Practicum Reports: A Case Study. Journal of Education for Teaching, 45(5), 605-607. https://doi:10.1080/02607476.20 19.1675355 .

Lindqvist, H., M. Weurlander, A. Wernerson, \& R. Thornberg. (2017). Resolving Feelings of Professional Inadequacy: Student Teachers' Coping with Distressful Situations. Teaching and Teacher Education, 64, 270-279. doi:10.1016/j. tate.2017.02.019

Martinez Agudo, J. D. D. (Ed.). (2018). Emotions in second language teaching: Theory, research and teacher education. 
Springer. https://doi.org//10.1007/978-3-319-75438-3

Madalińska-Michalak J., \& Bavli B. (2018). Developing Emotional Competence for L2 Teaching in Second Language Teacher Education: Opportunities and Challenges for Teacher Education in Poland and Turkey. In Martínez Agudo J. D. D. (Ed) Emotions in Second Language Teaching. Springer. https://doi.org/10.1007/978-3-319-75438-3_22

Nguyen M.H. (2018) ESL Teachers' Emotional Experiences, Responses and Challenges in Professional Relationships with the School Community: Implications for Teacher Education. In: Martínez Agudo J. D. D. (Ed) Emotions in Second Language Teaching. Springer. https://doi.org/10.1007/9783-319-75438-3_14

Nguyen, M. H. (2019). English language teacher education: A sociocultural perspective on preservice teachers' learning in the professional experience. Singapore: Springer.

Paker, T. (2011). Student teacher anxiety related to the teaching practicum. Eurasian Journal of Educational Research, 42, 207-224.

Petticrew, M., \& Roberts, H. (2006). Systematic reviews in the social sciences. Malden: Blackwell Publishing.

Richards, J. C. (2020). Exploring emotions in language teaching. RELC Journal, Advance online publication. https://doi. org/10.1177/0033688220927531

Shoffner, M. (2009). The place of the personal: Exploring the affective domain through reflection in teacher preparation. Teaching and Teacher Education, 25, 783-789. https://doi. org/10.1016/j.tate.2008.11.012

Shulman, L. S. (1987). Knowledge and teaching: Foundations of the new reform. Harvard Educational Review, 57(1), 1-23. doi:10.17763/haer.57.1.j463w79r56455411

Sutton, R. E., \& Wheatley, K. F. (2003). Teacher's emotions and teaching: A review of literature and directions for future research. Educational Psychology Review, 15(4), 327-358.

Tashma Baum, M. (2014). 'The aspect of the heart': English and self-identity in the experience of preservice teachers. Language and Intercultural Communication, 14(4), 407-422. doi:10.1080/ 14708477.2014.934379

Teng, F. (2017). Emotional development and construction of teacher identity: Narrative interactions about the preservice teachers' practicum experiences. Australian Journal of Teacher Education, 42(11), 117. https://doi.org/10.14221/ ajte.2017v42n11.8

Timoštšuk, l., \& Ugaste, A. (2012). The role of emotions in student teachers' professional identity. European Journal of Teacher Education, 35(4), 421-433. https://doi.org/10.1080 /02619768.2012.662637

Tum, D. O., \& Kunt, N. (2013). Speaking anxiety among EFL student teachers. Hacettepe Üniversitesi Eğitim Fakültesi Dergisi, 28(3), 385-399

Yuan, R., \& Lee, I. (2015). The cognitive, social and emotional processes of teacher identity construction in a pre-service teacher education programme. Research Papers in Education, 30, 469-491. https://doi.org/10.1080/02671522.201 4.932830

Yuan, R., \& Lee, I. (2016). 'I need to be strong and competent': A narrative inquiry of a student teacher's emotions and identities in teaching practicum. Teachers and Teaching, 22, 819-841. https://doi.org/10.1080/13540602.2016.1185819
Yüksel, H. G. (2014). Becoming a teacher: tracing changes in pre-service English as a foreign language teachers' sense of efficacy. South African Journal of Education, 34(3), 1-8. https://doi.org/10.15700/201409161104 